\title{
The Evaluation of Industrial Internship for Vocational School of Mechanical Engineering in Tegal
}

\author{
Ardani Ahsanul Fakhri*, Sudji Munadi \\ Graduate School Yogyakarta State University, Yogyakarta, Indonesia \\ *Corresponding author: ardaniahsanul_f.2017@student.uny.ac.id
}

Received October 03, 2019; Revised November 10, 2019; Accepted November 12, 2019

\begin{abstract}
This research aims to evaluate the implementation of industrial internship program on the aspects of: 1) planning, 2) process, and 3) results. In this study, the industrial internship is for the students of Vocational High School in Mechanical Engineering program. This research is a quantitative research with the respondents of teachers, students, and the industries in Tegal regency. The location of this research is in three Vocational High School (VHS) with an engineering program and the industries for students' internship. The data in this research was collected using questionnaire and analysis of descriptive statistics. The result shows that: (1) the planning of the internship is in the suitability level of $55 \%$ for students, $100 \%$ for teachers, and $65 \%$ for the industries; (2) the process of the internship is in the suitability level of $54 \%$ for students, $72 \%$ for teachers, and $60 \%$ for the industries; and (3) the result of the internship is in the suitability level of $55 \%$ for students, $100 \%$ for teacher, and $55 \%$ for the industries. In conclusion, the execution of the internship program of the VHS in Tegal is suitable for the stakeholders.
\end{abstract}

Keywords: Industrial internship, evaluation, mechanical engineering

Cite This Article: Ardani Ahsanul Fakhri, and Sudji Munadi, "The Evaluation of Industrial Internship for Vocational School of Mechanical Engineering in Tegal." American Journal of Educational Research, vol. 7, no. 11 (2019): 806-809. doi: 10.12691/education-7-11-8.

\section{Introduction}

Vocational High School is a part of education which prepares students to work in a specific field. VHS educates the students with competences that they can have specifications that they can apply in the job field. The idea is in line with the Government Regulation Number 29 Year 1990 about middle school education chapter 1 article 1 section 3 that "middle school education aims to develop students' skills to do a specific job". Meanwhile, in chapter II article 3 section 2, "middle school education aims to prepare students for work and professional career".

Currently, VHS faces the problem of graduates' employability. Based on the Indonesian Central Bureau of Statistics on February 2019, the level of Vocational High School graduates' open unemployment in Indonesia is the highest in the number of $8.63 \%$ followed by Diploma I/II/III (6.89\%), Senior High School (6.78\%), University (6.24\%), Senior High School (5.04\%), and Primary school (2.65\%). The data from the Central Java's Central Bureau of Statistics shows that in Feruary 2019, the number of open unemployment from Vocational Education is 8.63\% [1]. The high number of unemployment in local and national level shows that there is not any correlation between job vacancy and the number of VHS graduates. The difference in the SKKNI (National Working Qualification Standard of Indonesia) to the working world is the strongest reason which causes the high number of VHS graduates' unemployment. In [2], the SKKNI does not have real influence to the competence of human resources and its development. Hence, SKKNI is not a reference for the Vocational Competence Test for the students.

Looking at the problems above, the Instruction of President Number 9 Year 2016 reshuffled the system of education and vocational training. The president emphasizes that there should be a revitalization of VHS, so that human resources can improve. The instruction ask the Ministry of Education and Culture to frame, perfect, and harmonize the curriculum of VHS with the working world (Link and Match) [3].

The revitalization of VHS is instructed by the presidents for five goals: 1) actualizing the link and match of VHS with the working world, 2) changing the view for VHS which only produces graduate without concerning on the job market and adjust to the skills needed in the working world, 3) changing the learning of supply driven to demand driven, 4) preparing the graduates of VHS to adapt with the changes in the world and be employable, success in entrepreneur, or pursuing higher education, 5) reducing the gaps between higher education and the needs of working world in all aspects [4].

The revitalization aims to actualize Link and Match by executing Industrial Internship for the students. Through the program, the students can know how to work in the real life as well as practice their competence in the real working environment. The implementation of internship is based on the Decree of Ministry of Culture and Education Number 232/u/1997 regarding the implementation of VHS industrial internship. Industrial internship is a program of 
training for the students to work in the working world and to improve their competence based on their fields. The another definition of this is internship aims to give students clear learning goals [5]. Education gives students chance to get experiences beyond the theories they have learned [6]. The learning model of the internship gives students significant contribution in developing their working fields [7].

Industrial internship mainly happens for VHS students in grade two. In some schools, the students have the industrial internship in their third grade. The practice happens for three months in the industry, whether in a small scale-industry or in a big scale. The flow of the internship starts from planning, execution, and scoring. The planning starts from competence, industrial choice, program's arrangement, students' preparation, and the arrangement for students' supervisor. The execution of the internship starts from journaling, monitoring by supervising teacher, and documentation. Meanwhile, the evaluation starts with the scoring from the supervisor, certification, and reporting [8].

Industrial internship helps the school to achieve goals of curriculum's revitalization. In [9], the management of VHS internship is a concrete step to reduce the gaps between VHS and the industry. Students' working experience is the predictor of their way to find a job [10]. Industrial internship upgrades the curriculum about working environment and its adaptation for VHS education. The program can also improve the soft skill and hard skill competence. According to [11], internship impacts students' personal enhancements significantly; these values are confidence, interpersonal skills, and cooperation. Based on [12], internship has positive consequence on students' skills and competence development. The main effect of the competence can be seen through the implementation of theoretical understanding in practice, technical competence, and personal competence. Also, internship helps the students changing their perception from negative to positive. In [13], social experience of students in working directs them to change their perspective about their job.

Internship can reduce the anxiety of the students. Based on [14], students' confidence and skills develop significantly. Many positive impacts are proven from internship. In order to know the effectiveness of industrial internship program, there should be an evaluation to the program.

The evaluation of the program should be the basis of the school and officials of education to determine the effectiveness of the program.

\section{Research Methodology}

This research aims to evaluate the execution of industrial internship for Vocational High School students based on three steps, which are: 1) planning, 2) execution, and 3) result. Three steps of this research are conceptualization, data collection, analysis, and final report. The objects of this research are the teachers, students, and the representative from the industry. The sampling of this research uses purposive sampling method where there are three schools with 14 teachers, 84 students, and 20 industries. Table 1 mentions the details regarding the stakeholders in this research.

Table 1. The list stakeholders, including schools, teachers, and the partnering industries

\begin{tabular}{ccccc}
\hline \multirow{2}{*}{ No } & \multirow{2}{*}{ Schools } & \multicolumn{3}{c}{ Total } \\
\cline { 3 - 5 } & & Teachers & Teachers & Teachers \\
\hline 1 & SMK N 1 Adw & 5 & 45 & 10 \\
\hline 2 & SMK Is Adw & 5 & 17 & 5 \\
\hline 3 & SMK Muh Adw & 4 & 22 & 5 \\
\hline
\end{tabular}

This research employes descriptive quantitative design, evident from the questionnaire as the method of data collection. The questionnaire is developed based on the variable of the research. The questions of the students were arranged and developed based on the indicators in 4 Likert-scale points $(1=$ poor, $2=$ fair, $3=$ good, $4=$ excellent). The respondents could tick their answer to response it.

The data from the questionnaire were analysed using 1) variable's distribution of frequency, 2) central tendency (Mean, Median, Mode), and 3) the spread of the size which includes the standard of deviation. The data can be classified based on the categories as in Table 2.

Table 2. The Suitability of Industrial Internship

\begin{tabular}{lll}
\hline No & Score Range & Categories \\
\hline 1 & $>(\mathrm{Mi}+1,5 \mathrm{SDi})-(\mathrm{Mi}+3 \mathrm{SDi})$ & Very Suitable \\
\hline 2 & $>(\mathrm{Mi})-(\mathrm{Mi}+1,5 \mathrm{SDi})$ & Suitable \\
\hline 3 & $>(\mathrm{Mi}-1,5 \mathrm{SDi})-(\mathrm{Mi})$ & Fairly suitable \\
\hline 4 & $(\mathrm{Mi}-3 \mathrm{SDi})-(\mathrm{Mi}-1,5 \mathrm{SDi})$ & Not suitable \\
\hline
\end{tabular}

Mi: $\frac{\text { Highest Score+Lowest Score }}{2}$

SDi: $\frac{\text { Highest Score-Lowest Score }}{2}$

$\mathrm{Mi}=$ Ideal average and SDi $=$ Ideal Standard of Deviation [15].

\section{Results and Discussion}

Industrial internship is a program which aims to produce link and match between VHS and the industries. It is expected that the program can give the students relevant competence for the working world. The relevance is in line with the Regulation Number 20 Year 2003 in the explanation of article 15 that "VHS is a system which prepares the students to work in a specific department".

The description shows the importance of link and match in the industrial internship program. The programs gives a description of how the program works; thereby, there will be an information on the suitability of the program with the initial intention of why it exists. In order to show the relevance, this research gathers the data on the planning, execution, and the results of the industrial internship.

\subsection{The Planning of Industrial Internship}

The planning of industrial internship starts from four indicators: the goal of the program, socialization, preparation, and the funding. The analysis of the program is displayed in Figure 1. 


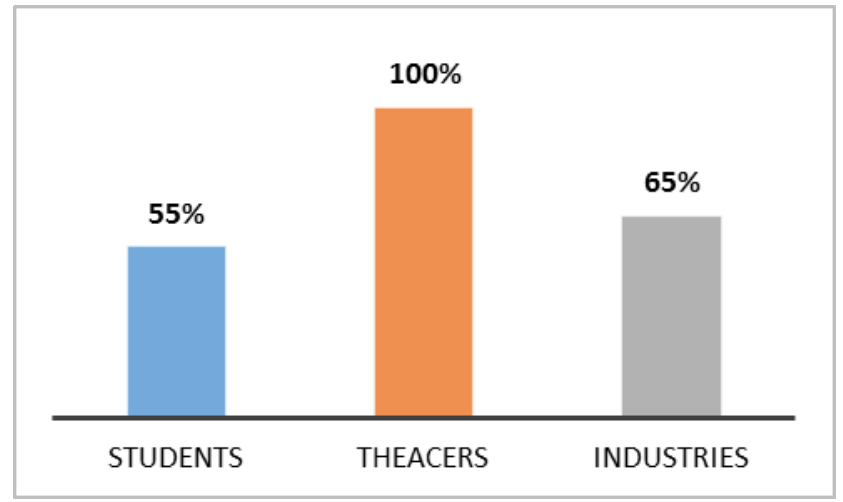

Figure 1. The rate of Industrial Internship’s suitability

Figure 1 shows that the planning of industrial internship reaches the suitability level of 55\% for students, $100 \%$ for teachers, and $65 \%$ for the industries. From all results, the program is considered suitable for the educational system. Based on the planning, the program works well even though only the teachers completely agree to its success.

From the four sub-categories of planning, there should be a good coordination between the platform. Planning is important for a program since it impacts the program. [16] mentions that the planning of internship, industrial involvement, and students' commitment positively influence the satisfaction of the internship experience. Also, the planning of the program influences the students' decision to continue working on their fields or not.

\subsection{The process of the Industrial Internship}

The process of the internship has three sub-categories: monitoring, participation, and cooperation. The analysis of the data is projected in Figure 2.

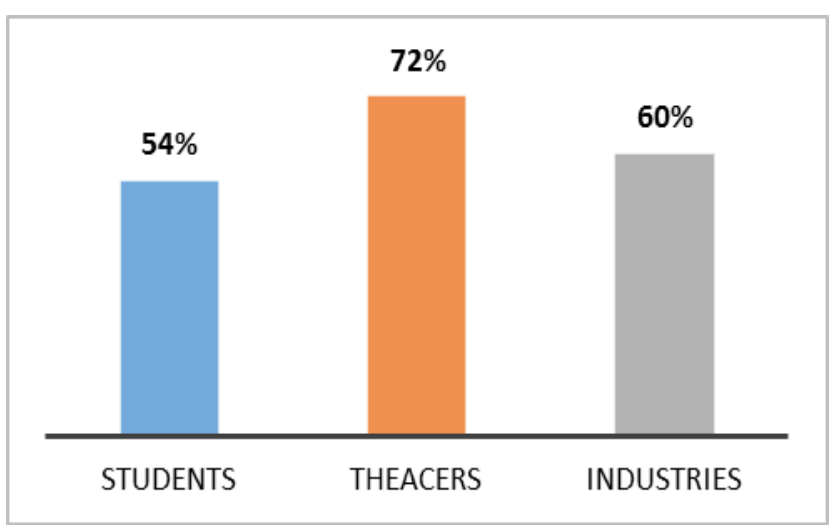

Figure 2. The suitability of the process of the industrial internship

Based on Figure 2, the process of the internship is considered suitable which score $54 \%$ for the students, $72 \%$ for the teachers, and $60 \%$ for the industries. The data shows that the sub-categories have different responses from the stakeholders.

The process of the internship influences the overall program. The phase influence the experience obtained by the students during the practice. The experience is important to determine whether the students are ready to work and be motivated in working. Based on [17], the experience of internship has positive and significant influence to the students, since they will do the job really well.

\subsection{Outcome of the Internship}

The outcome of the internship depends on the improvements of students' competence and the evaluation for the students, which include their certification. Figure 3 shows that the program of the internship has the suitability of $67 \%$ to the students, $100 \%$ for the teachers, and the $55 \%$ for the industry. The three respondents' score shows that the students have suitable outcome for their working fields.

The outcome came from good planning and execution. Without these aspects, the program will not work well. Furthermore, all aspects are correlated to each other. As in [18], the comfortability in working, accepting workmates' trait, and acquiring new skills have positive influence to students' career development. Students, who are enthusiast during the program, will take a lot of knowledge and competence based benefits.

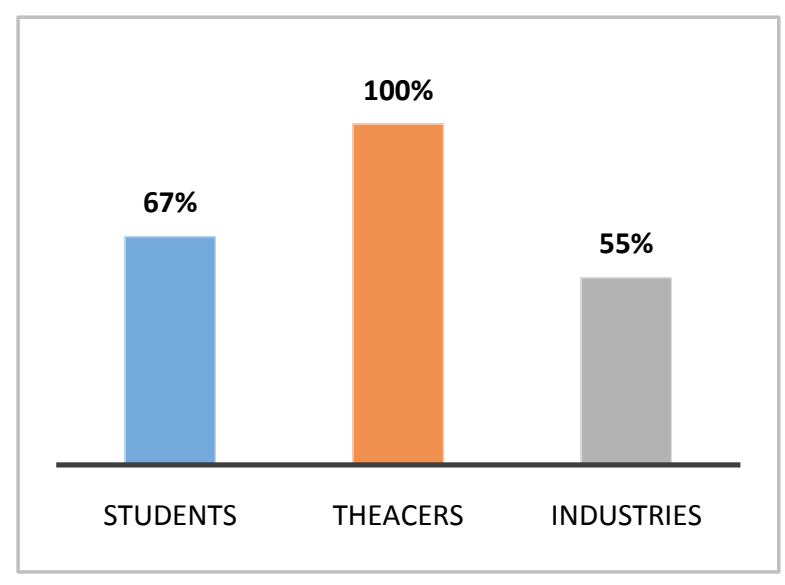

Figure 3. The suitability of the outcome of the industrial internship

This enthusiasm changes their working ethics during and after the program. Lastly, the overall comparison of the program is shows in Figure 4.

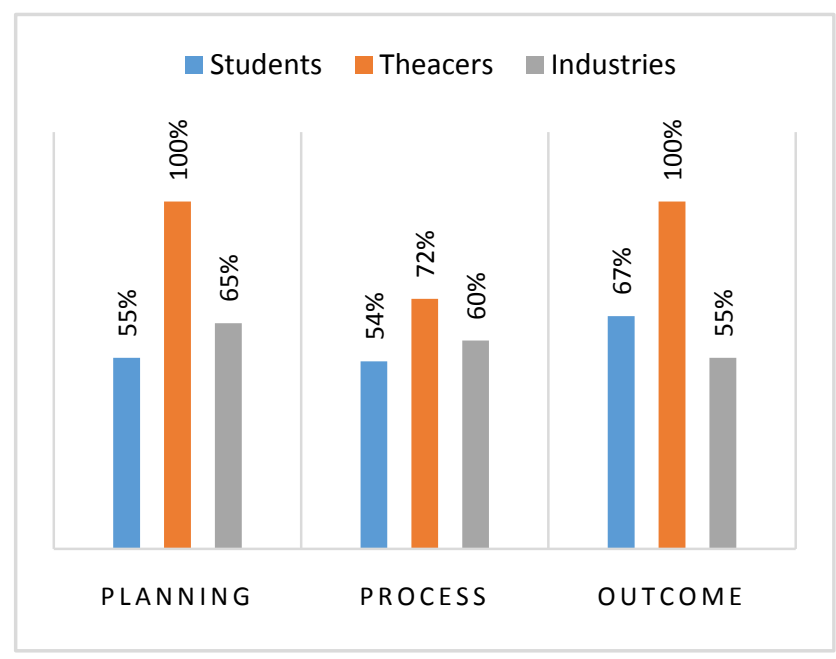

Figure 4. The percentage of students' overall experience in the industrial internship

\section{Conclusion}

The evaluation for the planning of industrial internship for VHS students has the highest score from the teacher, 
which is $100 \%$, followed by students (55\%), and the industries (65\%). The variables of the planning are the goal of the program, socialization, preparation, and the funding. These variables influences the stakeholders' decision during the planning of the program.

The evaluation of the execution of the industrial internship shows that the teacher responses in $72 \%$, followed by students and the industries, which are $54 \%$ and $60 \%$ respectively. The variables of the execution are monitoring, participation, and cooperation. These variables affect the different result of the data.

The evaluation of internship's outcome has the highest score to the teacher with $100 \%$, students with $67 \%$, and the industries with 55\%. The variables of the evaluation are the improvements of students' competence and the evaluation and certification for the students. The variables affect the stakeholders differently during the program.

The overall evaluation to the industrial internship shows that the three data is correlated to each other to make the program's succeed. During the internship, teachers scored the highest, which is different to the students and the industries. The high responses on the teachers and the industries do not affect the students. The absence of the influence shows that all stakeholders should work together to make the programs suitable for them and effective to achieve the national goals of VHS education.

\section{References}

[1] Badan Pusat Statistik. "Keadaan Ketenagakerjaan Indonesia Februari 2019”, Badan Pusat Statistik, Jakarta, Indonesia, No.41/05/Th XXII, May 06, 2019.

[2] Mahdane, Afri, dkk. 2018. Pengaruh SKKNI dan Kompetensi SDM terhadap Pengembangan SDM di Unit Profesi SDM dalam Menghadapi Era MEA.

[3] Presiden Republik Indonesi, Instruksi Presiden Republik Indonesia No. 9 Tahun 2016 tentang Revitalisasi Sekolah Menengah Kejuruan dalam Rangka Peningkatan Kualitas dan Daya Saing Sumber Daya Manusia Indonesia, Sekertariat Kabinet Republik Indonesia: Jakarta, 2016.

[4] Hadam, Sampun dkk. 2017. Strategi Implementasi Revitalisasi
SMK. Jakarta Pusat. Direktorat Pembinaan Sekolah Menengah Kejuruan.

[5] M. Stanton, Internships: Learning by doing. Occupational outlook quarterly, 36, 30-34 (1992).

[6] Franks, P.C \& Oliver, G.C. Experiental learning and international collabiration opportunities: Virtual Internship. Library Review Vol.61 No. 4, 2012.

[7] Naidoo, Serena, et al. Training the next generation of clinical researchers: evaluation of a graduate podiatrist research internship in rheumatology. Journal of Foot and Akle Research.

[8] Direktorat Pembinaan SMK. 2017. Buku Panduan PKL. Direktorat jenderal pendidikan dasar dan menengah, Kementerian pendidikan dan kebudayaan

[9] Wibowo,N.Upaya Memperkecil Kesenjangan Kompetensi Lulusan Sekolah Menengah Kejuruan dengan Tuntutan Dunia Industri. Jurnal Pendidian Teknologi dan Kejuruan, Volume 23, Nomor I, Mei 2016.

[10] Gamboa, Vitor, Maria Paula Paixao, \& Saul Neves de Jesus. Internship quality predicts career exploration of high school students. Journal of Vocational Behavior, 2013, Volume 83.

[11] A Scicluna, Helen, et al. Improving the transition from medical school to internship - evaluation of a preparation for internship course. BMC Medical Education 2014.

[12] Albu, Nadia and Calu, Daniela Artemisa St. and Guse, Raluca, The Role of Accounting Internships in Preparing Students' Transition from School to Active Life (March 31, 2016). Accounting and Management Information Systems Vol. 15, No. 1, pp. 131-153, 2016.

[13] Tocco, Nikki et al. Innovation in internship preparation: an operative anatomy course increases senior medical students' knowledge and confidence. The American Journal Of Surgery, 2013, Vol 206.

[14] Kim, Hong-bumm, \& Erin Jinok Park. The role of social experience in undergraduates' career perceptions through internships. Journal of Hospitality, Leisure, Sport \& Tourism Education. 2013, Volume 12.

[15] Wagiran. 2013. Metodologi Penelitian Pendidikan. Teori dan Implementasi. Yogyakarta: CV. Budi Utama

[16] Chen, Tzu-Ling, Ching-Cheng Shen. Today's intern, tomorrow's practitioner?-The influence of internship programmes on students' career development in the Hospitality Industry. Journal of Hospitality, Leisure, Sport \& Tourism Education, 2012, Vol 11.

[17] Lestari, Isnania, \& Budi Tri Siswanto. Pengaruh Pengalaman Prakerin, Hasil Belajar Produktif Dan Dukungan Sosial Terhadap Kesiapan Kerja Siswa SMK. Jurnal Pendidikan Vokasi. 2015. Vol 5.

[18] Jawabri, Adnan.Exploration of Internship Experience and Satisfaction Leading to Better Career Prospects among Business Students in UAE. American Journal of Educational Research, vol. 5, no. 10 (2017): 1065-1079. 